\title{
Isolation and Molecular Detection of Gram Negative Bacteria Causing Urinary Tract Infection in Patients Referred to Shahrekord Hospitals, Iran
}

\author{
Elahe Tajbakhsh ${ }^{1, *} ;$ Sara Tajbakhsh ${ }^{2} ;$ Faham Khamesipour $^{3,4}$ \\ ${ }^{1}$ Department of Microbiology, Faculty of Basic Sciences, Shahrekord Branch, Islamic Azad University, Shahrekord, IR Iran \\ ${ }^{2}$ School of Nursing, Shahrekord University of Medical Sciences, Shahrekord, IR Iran \\ 3 Young Researchers and Elite Club, Shahrekord Branch, Islamic Azad University, Shahrekord, IR Iran \\ ${ }^{4}$ Faculty of Veterinary Medicine, Shahrekord Branch, Islamic Azad University, Shahrekord, IR Iran \\ *Corresponding Author: Elahe Tajbakhsh, Department of Microbiology, Faculty of Basic Sciences, Shahrekord Branch, Islamic Azad University, Shahrekord, IR Iran. Tel: +98-9131841012, \\ Fax:+98-3833361060, E-mail: ee_tajbakhsh@yahoo.com
}

Received: October 23, 2014; Revised: February 21, 2015; Accepted: March 6, 2015

\begin{abstract}
Background:Urinary Tract Infections(UTI), and their complications, cause serious health problems, which affect millions of people every year. Infections of the urinary tract are the second most common type of infection in the body and approximately $20 \%$ of women are especially prone to UTIs for reasons not yet well understood. Urinary Tract Infections in men are not as common as in women yet can be very serious when they do occur. Accurate identification of bacterial isolates is an essential task of the clinical microbiology laboratory. Objectives: The purpose of this study was to determine the incidence and variety of the causative microbial agents of UTIs in patients who had referred to a medical laboratory of Kashani and Hajar hospital in Shahrekord, Iran.

Patients and Methods: In this cross-sectional study 147 urine samples of patients (urine test results were positive for UTIs) were examined during April to September 2013. A total of 147 urine samples of patients with clinical symptoms of UTI who had been referred to a medical laboratory of Kashani and Hajar hospital in Shahrekord (Iran), were collected and processed immediately for laboratory analysis.

Results: Escherichia coli was identified as the most common causative agent of UTIs (51.70\% of total isolates in both sexes), followed by Klebsiella pneumoniae (K. Pneumoniae) (16.32\%). Frequency of Proteus spp., Acinetobacter spp., Entrobacter spp., Citrobacter spp., Pseudomonas aeruginosa (P. aeruginosa) and Providencia spp. was 10.88\%, 6.12\%, 5.44\%, 4.08\%, 3.40\% and 2.04\%, respectively. Statistical analysis by Fisher exact test showed that there was no significant relationship between the type of bacteria and gender $(\mathrm{P}>0.05)$. Chi square test showed that there was no significant relationship between the type of bacteria and the use of catheter and age group $(\mathrm{P}>0.05)$. However, there was a significant relationship between the type of bacteria and the history of hospitalization $(\mathrm{P}>0.05)$.

Conclusions: Our findings implied that a wide range of bacteria could be involved in creating urinary tract infection in patients referred to a medical laboratory of Kashani and Hajar hospital in Shahrekord, Iran. Regardless of age, sex and the use of catheter, a wide range of bacteria could be involved in urinary tract infections.
\end{abstract}

Keywords: Gram-Negative Bacteria; Isolation; Molecular Detection; Urinary Tract Infections

\section{Background}

Urinary Tract Infections (UTIs) are one of the most common bacterial infections in humans, both in community and hospital settings (1). It has been estimated that globally, symptomatic UTIs result in as many as seven million visits to outpatient clinics, one million visits to emergency departments, and 100,000 hospitalizations, annually (2-6). In recent studies microbial species that cause UTIs are classified by their target sites, such as urine infection (bacteriuria), bladder infection (cystitis) and kidney infection (pyelonephritis), which can be either asymptomatic or associated with symptoms (7). Prevalence of infection differs with age, sex and certain predisposing factors (8). The distribution of these bacteria is different in different parts of the world and studying the microbial factors that cause this infection in different geographical regions, indicates their dispersion (8).

Urinary Tract Infections involve the infection of kid- neys, ureters, bladder, and/or urethra by pathogenic organisms invasion of the urinary tract, which ultimately leads to an inflammatory response of the urothelium. Prevalence of infections may differ with age, sex and certain predisposing factors. The incidence of infection is greater in females than in males with two exceptions, infections found in infants and catheter-related infections. Women tend to become infected by UTIs more often because their urethra is shorter and closer to the anus than men and hence, the pathogenic bacteria have easier access to the bladder (8).

The etiological agents of community-acquired and hospital-acquired UTIs differ (9-12). Only a limited amount of data has been published regarding changes in the frequency of causative agents among outpatients (6). Enteric bacteria (particularly Escherichia coli) have been and remain the most frequent cause of UTIs in anatomically

Copyright ( 2015, Iranian Red Crescent Medical Journal. This is an open-access article distributed under the terms of the Creative Commons Attribution-NonCommercial 4.0 International License (http://creativecommons.org/licenses/by-nc/4.0/) which permits copy and redistribute the material just in noncommercial usages, provided the original work is properly cited. 
normal, unobstructed urinary tracts. After Escherichia coli (E. coli), the other more common UTI-pathogens include Staphylococcus saprophyticus (S. saprophyticus), Enterococcus spp., Pseudomonas aeruginosa (P. aeruginosa), Candida spp., Klebsiella pneumonia (K. pneumonia), Proteus spp. and Enterobacter spp. (13-19). Bronsema et al. (1993) have reported that from 1980 to 1991, the percentage of UTIs caused by E. coli, Proteus species and Pseudomonas species had decreased, whereas the percentage of UTIs caused by yeasts, group B streptococci, and K. pneumoniae had increased (18). Weber et al. (1997) have also reported changes in the causative agents of UTIs including, a decrease in the percentage of UTIs caused by Enterobacter species, but an increase in UTIs caused by Acinetobacter species and $P$. aeruginosa. Among the fungal agents, Candida albicans (C. albicans) is the most common cause of funguria, followed by C. glabrata, C. tropicalis, C. parapsilosis, C. krusei, and other yeasts (20). Identification of bacterial isolates is an essential task of clinical microbiology laboratories. In clinical laboratories, the present means of identification of bacteria relies on phenotypic tests. Traditional phenotypic identification is difficult and time consuming (8). In the late 1906 - 1910, genotypic identification emerged as an alternative or complement to the established phenotypic methods. Typically, genotypic identification of bacteria involves the use of conserved sequences within phylogenetically informative genetic targets, such as the small-subunit (16S) rRNA gene. Sequence analysis of the $16 \mathrm{~S}$ ribosomal RNA (rRNA) gene has been widely used to identify bacterial species and diagnose microbial infections. However, these methods are yet to replace standard bacterial culture due to their prohibitive costs, complexity, and the need for highly-trained personnel (21-23).

The risk factors associated with UTIs include immunosuppression, trauma, foreign body, broad-spectrum antibiotic use, infused body fluids such as saline irrigations and also, urinary catheterization (18).

\section{Objectives}

The purpose of this study was to determine the incidence and population of the causative microbial agents of UTIs in patients who had referred to a medical laboratory of Kashani and Hajar hospital in Shahrekord, Iran.

\section{Patients and Methods}

\subsection{Sample Size Determination and Inclusion Criteria}

A sample size calculation was performed using the following Equation:

$$
n=\frac{Z^{2} P(P-1)}{d^{2}}
$$

Where $\mathrm{n}=$ sample size, $\mathrm{Z}=\mathrm{Z}$ statistic corresponding to $\mathrm{a}$ chosen level of confidence, $P=$ expected prevalence, and $\mathrm{d}=$ precision (24). In our calculation, we used $\mathrm{Z}=\mathrm{Z}$ score for $95 \%$ confidence interval $=1.96, P=0.11$, and $d=0.05$ (25). The study included all affected children and adults who were not on current antibiotic therapy and were willing to participate.

\subsection{Samples and Bacterial Identification}

Between April and September 2013, a total of 147 urine samples of patients with clinical symptoms of UTI, that had been referred to the medical laboratory of Kashani and Hajar hospital in Shahrekord, Iran, were collected.

Clean catch $5 \mathrm{~mL}$ of Midstream Urine Samples (MSU) were collected using leak proof re-usable and sterilizable wide mouthed plastic containers and transported immediately to the laboratory. All of the specimens were analyzed within an hour of collection. Socio-demographic variables (age, sex and other relevant clinical data such as history of catheterization and history of UTI) were obtained using a pre-designed structured questionnaire.

Bacteria were identified using conventional microbiological methods. For bacteriological analysis, MacConkey agar (Merck, Germany) and Eosin Methylene Blue agar (EMB agar) (Merck, Germany) plates were used. Semi-quantitative urine culture using a calibrated loop was prepared and incubated under both aerobic and anaerobic conditions for 24 hours at $37^{\circ} \mathrm{C}$. With a calibrated loop, $0.01 \mathrm{~mL}$ of urine sample was streaked aseptically in MacConkey agar and EMB agar. The plates were then incubated aerobically at $37^{\circ} \mathrm{C}$ for 24 hours. Bacterial identification was done by examination of the overnight culture and Gram staining. Samples with colony counts equal to or more than $10^{5} \mathrm{Cfu} / \mathrm{mL}$ were considered positive $(7,26)$. The identification of Gram-negative bacteria was performed by standard biochemical tests (catalase, oxidase, IMViC (indole, methyl red, VogesProskauer, and citrate) tests, $\mathrm{H}_{2} \mathrm{~S}$ production, lysine decarboxylase, lactose fermentation, urea hydrolysis and gas production) (7).

\subsection{DNA Extraction}

Bacterial strains were subcultured overnight in LuriaBertani broth (Merck, Germany) and genomic DNA was extracted from typical colonies of E. coli using a DNA extraction kit (DNPTM, CinnaGen, Iran), according to manufacturer's instructions.

\subsection{Polymerase Chain Reaction for the Detection of Bacterial Causing Urinary Tract Infections}

Polymerase Chain Reaction (PCR) was used for the amplification of 16srRNA genes. The details of the primers used in the study are given in Table 1 . In the present study, various PCR assays were used for the detection of 
Tajbakhsh E et al.

bacteria causing UTIs. The PCR assay was carried out in a total volume of $50 \mu \mathrm{L}$ of a mixture containing PCR buffer $10 \times, 1.5 \mathrm{mM}$ of $\mathrm{MgCl}_{2}, 250 \mu \mathrm{M}$ of each of deoxynucleoside triphosphates, $0.5 \mu \mathrm{M}$ of each of specific primers, $1.5 \mathrm{U}$ of Taq polymerase (Sigma), and $5 \mu \mathrm{L}$ of template DNA. The amplification conditions are shown in Table 2. The amplified products were visualized using ethidium bromide staining and gel electrophoresis done on 1.5\% agarose.

\subsection{Ethical Issues}

This study was approved by the Ethical Committee of the Islamic Azad University of Shahrekord, and Infertility and, Kashani and Hajar hospitals of Shahrekord, Iran, (registration number 1393/2021).

\subsection{Statistical Analysis}

The data were analyzed using the SPSS software (Version 18.SPSS). Statistical analysis was performed using Chisquare and Fisher's exact tests to determine significant correlations between gender, sex, age, history of hospitalization, the use of catheter and the type of bacteria. Statistical significance was considered at a $\mathrm{P}<0.05$.

\section{Results}

Identification of all UTIs causative microorganisms was performed by classic microbiological methods. Bacteria isolates were confirmed using PCR for all 147 urine specimens that originated from a sample of $70.06 \%$ females (103/147) and 29.23\% males (44/147).
In this study, E. coli was identified as the most common causative agent of UTIs (51.70\% of total isolates in both sexes), followed by K. Pneumonia (16.32\%). Frequency of Proteus spp., Acinetobacter spp., Entrobacter spp., Citrobacter spp., P. aeruginosa and Providencia spp. was $10.88 \%$, $6.12 \%, 5.44 \%, 4.08 \%, 3.40 \%$ and $2.04 \%$, respectively. Frequency of UTIs isolated from urine samples in Shahrekord is shown in Table 3.

In this study, E. coli was the most common bacteria in men (17\%) and women (34.7\%). The results are shown in Table 4. Statistical analysis by Fisher's exact test showed that there was no significant relationship between gender and the type of bacteria $(\mathrm{P}>0.05)$.

The patients of this study were divided to five age groups (1-19, 20 - 29, 30 - 39, 40 - 49 and > 45). The highest rates of urinary tract infections were seen in 20 - 29 year olds. The results are shown in Table 5. Statistical analysis using Chi square test showed that there was no significant relationship between age group and the type of bacteria $(\mathrm{P}>0.05)$.

From a total of 147 patients, 85 patients had a history of hospitalization. Escherichia coli was identified as the most common causative agent of UTIs (51.7\%) in patients with and without a history of hospitalization, this was followed by K. pneumonia (16.3\%), while the other bacteria such as Proteus spp, Acinetobacter spp., Entrobacter spp., Citrobacter spp., P. aeruginosa and Providencia spp. were the causative agent of $32 \%$ of UTIs. The results are shown in Table 6. Statistical analysis using Chi square test showed that there was a significant relationship between the type of bacteria and the history of hospitalization ( $\mathrm{P}$ $<0.05)$.

\begin{tabular}{|c|c|c|c|c|}
\hline Bacteria & $\begin{array}{l}\text { Primer Oligonucleotide } \\
\text { sequences (5'-3') }\end{array}$ & $\begin{array}{l}\text { Gene bank Accession } \\
\text { number or reference }\end{array}$ & $\begin{array}{l}\text { Amplicon } \\
\text { size (bp) }\end{array}$ & $\begin{array}{c}\text { Annealing } \\
\text { Temperature }\left({ }^{\circ} \mathrm{C}\right)\end{array}$ \\
\hline Escherichia coli & $\begin{array}{l}\text { F: AGAGTTTGATCMTGGCTCAG } \\
\text { R: CCGTCAATTCATTTGAGTTT }\end{array}$ & 000913.3 & 919 & 59 \\
\hline Klebsiella penumoniea & $\begin{array}{l}\text { F: CAAGTCGAGCGGTAGCACAGAG } \\
\text { R: ACCGTGTCTCAGTTCCAGTGTG }\end{array}$ & EU828348 & 274 & 62 \\
\hline Proteus spp. & $\begin{array}{l}\text { F: ACTTGGGAATTGCATCTGAAACTG } \\
\text { R: ACATCGTTTACAGCGTGGACTACC }\end{array}$ & KJ453110.1 & 201 & 59 \\
\hline Enterobacter spp. & $\begin{array}{l}\text { F: ATGTCTGGGAAACTGCCTGATG } \\
\text { R: CGGGTAACGTCAATAGACAAGG }\end{array}$ & KF872714.1 & 372 & 60 \\
\hline Citrobacter spp. & $\begin{array}{l}\text { F: TAATACCGCATAACGTCGCAAG } \\
\text { R: CTTCTTCTGCGAGTAACGTCAATG }\end{array}$ & KF012641.1 & 331 & 59 \\
\hline Acinetobacter spp. & $\begin{array}{l}\text { F: ATGCAAGTCGAGCGGAGATGAG } \\
\text { R: TACCCCACCAACTAGCTAATCCG }\end{array}$ & JX966369.1 & 202 & 62 \\
\hline Providencia spp. & $\begin{array}{l}\text { F: GTAGTCCACGCTGTAAACGATGTC } \\
\text { R:TCTGGATGTCAAGAGTAGGTAAGGT }\end{array}$ & KF217251 & 202 & 62 \\
\hline $\begin{array}{l}\text { Pseudomonas } \\
\text { aeruginosa }\end{array}$ & $\begin{array}{l}\text { F: AATACCTTGCTGTTTTGACGTTAC } \\
\text { R: TCAGTGTCAGTATCAGTCCAGGTG }\end{array}$ & JN791362 & 295 & 58 \\
\hline
\end{tabular}




\section{Tajbakhsh E et al.}

Table 2. Polymerase Chain Reaction Pro Gram for Detection of Gram Negative Bacteria Causing Urinary Tract Infections a

\begin{tabular}{|c|c|c|}
\hline \multirow{2}{*}{ Bacteria } & \multicolumn{2}{|c|}{ PCR program } \\
\hline & Degree, ${ }^{\circ} \mathrm{C}$ & Time, $s$ \\
\hline \multirow{8}{*}{ E. coli } & 1 cycle & \\
\hline & $95^{\circ} \mathrm{C}$ & 360 \\
\hline & 31 cycle & \\
\hline & $95^{\circ} \mathrm{C}$ & 45 \\
\hline & $59^{\circ} \mathrm{C}$ & 60 \\
\hline & $72^{\circ} \mathrm{C}$ & 60 \\
\hline & 1 cycle & \\
\hline & $72^{\circ} \mathrm{C}$ & 300 \\
\hline \multirow{8}{*}{ Klebsiella penumonia } & 1 cycle & \\
\hline & $94^{\circ} \mathrm{C}$ & 60 \\
\hline & 30 cycle & \\
\hline & $94^{\circ} \mathrm{C}$ & 60 \\
\hline & $63^{\circ} \mathrm{C}$ & 30 \\
\hline & $72^{\circ} \mathrm{C}$ & 90 \\
\hline & 1 cycle & \\
\hline & $72^{\circ} \mathrm{C}$ & 300 \\
\hline \multirow{8}{*}{ Proteus spp. } & 1 cycle & \\
\hline & $95^{\circ} \mathrm{C}$ & 60 \\
\hline & 31 cycle & \\
\hline & $95^{\circ} \mathrm{C}$ & 45 \\
\hline & $62^{\circ} \mathrm{C}$ & 30 \\
\hline & $72^{\circ} \mathrm{C}$ & 90 \\
\hline & 1 cycle & \\
\hline & $72^{\circ} \mathrm{C}$ & 300 \\
\hline \multirow{8}{*}{ Enterobacterspp. } & 1 cycle & \\
\hline & $95^{\circ} \mathrm{C}$ & 60 \\
\hline & 31 cycle & \\
\hline & $95^{\circ} \mathrm{C}$ & 45 \\
\hline & $62^{\circ} \mathrm{C}$ & 30 \\
\hline & $72^{\circ} \mathrm{C}$ & 90 \\
\hline & 1 cycle & \\
\hline & $72^{\circ} \mathrm{C}$ & 300 \\
\hline \multirow{8}{*}{ Citrobacter spp. } & 1 cycle & \\
\hline & $94^{\circ} \mathrm{C}$ & 60 \\
\hline & 30 cycle & \\
\hline & $94{ }^{\circ} \mathrm{C}$ & 60 \\
\hline & $63^{\circ} \mathrm{C}$ & 30 \\
\hline & $72{ }^{\circ} \mathrm{C}$ & 90 \\
\hline & 1 cycle & \\
\hline & $72{ }^{\circ} \mathrm{C}$ & 300 \\
\hline
\end{tabular}




\section{Tajbakhsh E et al.}

\begin{tabular}{|c|c|c|}
\hline \multirow{8}{*}{ Acinetobacter spp. } & 1 cycle & \\
\hline & $95^{\circ} \mathrm{C}$ & 120 \\
\hline & \multicolumn{2}{|l|}{30 cycle } \\
\hline & $95^{\circ} \mathrm{C}$ & 45 \\
\hline & $65^{\circ} \mathrm{C}$ & 30 \\
\hline & $73^{\circ} \mathrm{C}$ & 30 \\
\hline & \multicolumn{2}{|l|}{1 cycle } \\
\hline & $72^{\circ} \mathrm{C}$ & 600 \\
\hline \multirow{8}{*}{ Pseudomonas aeruginosa } & \multicolumn{2}{|l|}{1 cycle } \\
\hline & $95^{\circ} \mathrm{C}$ & 360 \\
\hline & \multicolumn{2}{|l|}{31 cycle } \\
\hline & $95^{\circ} \mathrm{C}$ & 45 \\
\hline & $61^{\circ} \mathrm{C}$ & 60 \\
\hline & $72^{\circ} \mathrm{C}$ & 60 \\
\hline & \multicolumn{2}{|l|}{1 cycle } \\
\hline & $72^{\circ} \mathrm{C}$ & 300 \\
\hline \multirow{8}{*}{ Providencia spp. } & \multicolumn{2}{|l|}{1 cycle } \\
\hline & $95^{\circ} \mathrm{C}$ & 360 \\
\hline & \multicolumn{2}{|l|}{31 cycle } \\
\hline & $95^{\circ} \mathrm{C}$ & 45 \\
\hline & $63^{\circ} \mathrm{C}$ & 60 \\
\hline & $72^{\circ} \mathrm{C}$ & 60 \\
\hline & \multicolumn{2}{|l|}{1 cycle } \\
\hline & $72^{\circ} \mathrm{C}$ & 300 \\
\hline
\end{tabular}

\footnotetext{
a Based on PCR pro Gram.
}

Table 3. Frequency of Bacteria Causing Urinary Tract Infections Isolated From Urine Samples in Shahrekord

\begin{tabular}{lc}
\hline Bacteria & Number of Isolates (\%) \\
\hline Escherichia coli & $76(51.70)$ \\
Klebsiella pneumonia & $24(16.32)$ \\
Proteus spp. & $16(10.88)$ \\
Acinetobacter spp. & $9(6.12)$ \\
Entrobacter spp. & $8(5.44)$ \\
Citrobacter spp. & $6(4.08)$ \\
Pseudomon asaeruginosa & $5(3.4)$ \\
\hline Providencia spp. & $3(2.04)$ \\
\hline
\end{tabular}

Table 4. Frequency of Bacteria Causing Urinary Tract Infections Isolated From Urine Samples of Males and Females a

\begin{tabular}{lccc}
\hline Bacteria & Number of Males, $\%$ & Number of Females, $\%$ & UTI, \% \\
\hline Escherichia coli & $25(17)$ & $51(34.7)$ & 51.70 \\
Klebsiella pneumonia & $7(4.76)$ & $17(11.56)$ & 16.32 \\
Proteus spp. & $5(3.40)$ & $11(7.48)$ & 10.88 \\
Acinetobacter spp. & $3(2.04)$ & $6(4.08)$ & 6.12 \\
Entrobacter spp. & $2(1.36)$ & $6(4.08)$ & 5.44 \\
Citrobacter spp. & $1(0.68)$ & $5(3.4)$ & 4.08 \\
Pseudomona saeruginosa & $1(0.68)$ & $4(2.72)$ & 3.40 \\
\hline Providencia spp. & $0(0)$ & $3(2.04)$ & 2.04 \\
\hline
\end{tabular}

a P Value $=0.763$. 
Tajbakhsh E et al.

\begin{tabular}{lcc}
\hline Table 5. Frequency of Gram Negative Bacteria in Patients Based on Age Groups ${ }^{\text {a }}$ & \\
\hline Age Groups, $\mathbf{y}$ & Number of Male, $\%$ & Number of Female, $\%$ \\
\hline $\mathbf{1}-\mathbf{1 9}$ & $6(13.63)$ & $18(17.4)$ \\
$\mathbf{2 0}-\mathbf{2 9}$ & $8(18.18)$ & $33(32.03)$ \\
$\mathbf{3 0}-\mathbf{3 9}$ & $13(29.54)$ & $26(25.24)$ \\
$\mathbf{4 0}-\mathbf{4 9}$ & $14(31.81)$ & $16(15.53)$ \\
$>\mathbf{4 9}$ & $3(6.81)$ & $10(9.70)$ \\
\hline Total & $44(100)$ & $103(100)$ \\
\hline
\end{tabular}

a $\mathrm{P}$ Value $=0.141$.

Table 6. Frequency of Gram Negative Bacteria in Patients With the History of Hospitalization ${ }^{\text {a }}$

\begin{tabular}{lccccc}
\hline Bacteria & History of Hospitalization $(+)$ & $\%$ & History of Hospitalization $(-)$ & $\%$ & UTI\% \\
\hline Escherichia coli & 51 & 60 & 25 & 40.3 & 51.7 \\
Klebsiella pneumonia & 14 & 16.5 & 10 & 16.1 & 16.3 \\
Other & 20 & 23.5 & 27 & 43.5 & 32 \\
\hline
\end{tabular}

$\mathrm{a}$ P Value $=0.028$, Statistical significance was regarded at a P value $<0.05$.

Table 7. Frequency of Gram Negative Bacteria in Patients With a History of the Use of a Catheter

\begin{tabular}{lccccc}
\hline Bacteria & The Use of Catheter $(+)$ & $\%$ & The Use of Catheter $(-)$ & $\%$ & UTI\% \\
\hline Escherichia coli & 37 & 59.7 & 39 & 45.9 & 37 \\
Klebsiella pneumonia & 11 & 17.7 & 13 & 15.3 & 11 \\
Other & 14 & 22.6 & 33 & 38.8 & 14 \\
\hline
\end{tabular}

In This study, from a total of 147 patients, 62 patients had used a catheter. In these patients, E. coli was identified as the most common causative agent of UTIs (37\%). The results are shown in Table 7. Statistical analysis using SPSS showed that there was no significant relationship between the type of bacteria and the use of catheter ( $P$ $>0.05$ ).

\section{Discussion}

Infection of the urinary tract is one of the most common infectious diseases affecting all age groups including men, women and children worldwide (23).

Urinary Tract Infection is one of the most common medical problems in females, who also made a large portion of patients in this study (70.06\%). Previous research has shown that female patients have much higher predisposition to UTIs than males (27). Statistical analysis using the SPSS software showed that there was no significant relationship between gender and the type of bacteria $(\mathrm{P}>0.05)$.

Several studies have demonstrated geographical variability of pathogen occurrence in the case of UTI among inpatient and outpatient populations (28). A variety of enteropathogenic bacteria are known to cause UTIs worldwide. Escherichia coli is the predominant etiological agent in community practice. Other bacterial agents include species of Klebsiella, Enterobacter, Proteus, Pseudomonas, Staphylococcus, Streptococcus and Enterococcus faecalis (28).
Results by Mirzaei et al. clearly showed that Gram-negative bacteria and family of Enterobacteriaceae are responsible for serious infections in humans (29). In the study of Aminzadeh et al. (2013), 122 (41.8\%) of the isolated clinical samples were Gram-negative Extended-Spectrum Betalactamase (ESBL)-producing bacteria , with most of them being E. coli (91.8\%), followed by K. pneumonia (8.2\%) (30).

Isolation of $E$. coli as the predominant pathogen of community-associated UTI has been extensively reported in many studies (28). However, the lower E. coli isolation $(51.70 \%)$ rate in our study remains unclear. However, similarly, a low rate of E. coli isolation has also been reported by other investigators from developed and developing countries. Nerurkar et al. (2012), reported that in Gram negative bacilli, the predominant isolate was the E.coli $(44.96 \%)$, followed by other bacilli like Enterobacter (17.83\%), Klebsiella spp. (14.72\%) and Citrobacter (12.4\%), amongst the major isolates. In this study, Klebsiella spp. was in second place (28). Our studies, similar to several previous reports, indicated that E. coli is still the most common cause of UTI in Shahrekord city (51.70\%). Piranfar et al. in their study reported that $E$. coli had the highest frequency among bacteria (64.56\%) followed by Klebsiella (13.58\%) (7). In a study conducted by Khameneh and Afshar., (31) from a total of 803 urine samples, the common microorganisms isolated were E. coli (78.58\%) followed by Klebsiella (5.48\%). The results of these two studies are similar to that of our research (32). However, the prevalence 
of infection differs with age, sex and certain predisposing factors. The incidence of infection has been shown to be greater in females than in males with two exceptions, infections found in infants and catheter-related infections $(33,34)$.

In our study, women in the 20 - 29 age group were most likely to suffer from UTIs, whether this is associated with being more sexually active has not been determined. Women are especially prone to UTIs for anatomical reasons. One factor is that a woman's urethra is shorter, allowing bacteria quicker access to the bladder. Also, a woman's urethral opening is near sources of bacteria from the anus and vagina. For women, the lifetime risk of having a UTI is greater than $50 \%$. Sexual intercourse increases the risk of symptomatic urinary tract infections (UTI) in young women (Table 5).

In a study conducted by Mirzarazi et al. from a total of 702 urine samples (476 females and 226 males), 203 samples (28.92\%) were positive for urine culture and had UTIs. The mean age was $37.07 \pm 22.2$ years (range from 1 month to 93 years). The sample of patients with UTIs consisted of $32.35 \%$ females (154 persons) and $21.68 \%$ males (49 persons). Also, Prevalence of E. coli, Klebsiella, Proteus and Pseudomonas were reported as $68 \%, 13 \%, 4 \%$ and $2 \%$ respectively (35).

Among the elderly, after 40 years of age, males became more prone to UTIs. The number of male patients increased significantly in 40 - 49 year-old. It is probable that with aging, prostatic gland enlargement and the decrease of bacteriostatic prostatic secretions, the risk of urinary tract infection is increased. This is similar to a research conducted by Noor et al. (8).

Statistical analysis using the SPSS software showed that there was no significant relationship between age group and the type of bacteria $(\mathrm{P}>0.05)$.

In a study conducted by Farajnia et al. it was indicated that E. coli was the predominant isolated pathogen from both sexes, yet the prevalence of UTI due to K. pneumoniae and $P$. aeruginosa was higher in men than in women (26). In our study, K. pneumonia was the second most common organism, followed by Proteus spp. Entrobacter, Citrobacter, Providencia and Pseudomonas spp. In a study conducted by Farajnia et al. K. pneumonia was the second most common cause of urinary tract infections (26). In many studies, it has been shown that Klebsiella spp. has the second place in causing UTIs, yet Shanthi and Kayathri, reported that Citrobacter was the second most frequently isolated microorganism (14\%) (34), which is not in accordance with other studies. On the other hand, Kashef et al. reported that Proteus spp. was the second most common organism followed by Klebsiella spp. and Pseudomonas spp. (36). The findings of this study matched the results of Getachew (27). In this study, a wide spectrum of uropathogens were isolated, of which $55.1 \%$ were E. coli, $16.4 \%$ Klebsiella species, 2.2\% Citrobacter species, 2\% Enterobacter species, 1.7\% Pseudomonas and 2.8\% Proteus species, Salmonella species and Acinetobacter species (27).
Other risk factors such as the use of a catheter and a history of hospitalization were included in the study. From a total of 147 patients, 85 patients had a history of hospitalization and 62 patients had used a catheter. Escherichia coli was identified as the most common causative agent of UTIs in patients with and without a history of hospitalization and patients who had used a catheter. Statistical analysis using the SPSS software showed that there was a significant relationship between the type of bacteria and a history of hospitalization $(\mathrm{P}<0.05)$, yet there was no significant relationship between the type of bacteria and the use of catheter $(\mathrm{P}>0.05)$. Regardless of age, sex and the use of catheter, a wide range of bacteria can be involved in creating urinary tract infections.

In conclusion, the PCR method provides a valuable tool for cheap and accurate diagnosis of Gram-negative bacteria in urinary tract infections, and can also be applicable for other infections.

\section{Authors' Contributions}

All authors contributed equally in preparing this manuscript.

\section{Financial Disclosure}

The authors declared that they had no conflicts of interest regarding the study design and findings.

\section{Funding/Support}

This work was supported by the Islamic Azad University, Shahrekord Branch, Shahrekord, Iran (Grant No. 8838).

\section{References}

1. Hryniewicz K, Szczypa K, Sulikowska A, Jankowski K, Betlejewska K, Hryniewicz W. Antibiotic susceptibility of bacterial strains isolated from urinary tract infections in Poland. J Antimicrob Chemother. 2001;47(6):773-80.

2. Ronald AR, Pattulo AL. The natural history of urinary infection in adults. Med Clin North Am.1991;75(2):299-312.

3. Foxman B. Epidemiology of urinary tract infections: incidence, morbidity, and economic costs. Am J Med. 2002;113(1):5-13.

4. Stamm WE. Scientific and clinical challenges in the management of urinary tract infections. Am J Med. 2002;113(1):1-4.

5. Noor N, Ajaz M, Sheikh Ajaz R, Pirzada ZA. Urinary tract infections associated with multidrug resistant enteric bacilli: characterization and genetical studies. Pakistan J Pharm Sci. 2004(17):115-23.

6. Wilson ML, Gaido L. Laboratory diagnosis of urinary tract infections in adult patients. Clin Infect Dis. 2004;38:1150-1158.

7. Piranfar V, Mirnejad R, Erfani M. Incidence and Antibiotic Susceptibility Pattern of Most Common Bacterial Pathogen Causing Urinary Tract Infection (UTI) in Tehran, Iran, 2012-2013. Int J Entric Pathog. 2014;2(1):e15490.

8. Noor AF, Shams F, Kishore S, Hassan MM. , Noor R. Prevalence and antibiogram profile of uropathogens isolated from hospital and community patients with urinary tract infection in Dhaka city. $J$ Bangladesh Aca Sci. 2013;37(1):57-63.

9. Maniatis AN, Trougakos IP, Katsanis G, Palermos J, Maniatis NA, Legakis NJ. Changing patterns of bacterial nosocomial infections: a nine-year survey in a general hospital. Chemotherapy. 1997;43(2):69-76.

10. Bouza E, San Juan R, Munoz P, Voss A, Kluytmans J, Co-operative Group of the European Study Group on Nosocomial Infections . 
A European perspective on nosocomial urinary tract infections II. Report on incidence, clinical characteristics and outcome (ESGINI-0 4 study). Clin Microbiol Infect. 2001;7(10):532-42.

11. Crude N, Tveten Y, Kristiansen B-E. Urinary tract infections in Norway: bacterial etiology and susceptibility. A retrospective study of clinical isolates. Clin Microbiol Infect. 2001;7(10):543-7.

12. Gupta K, Sahm DF, Mayfield D, Stamm WE. Antimicrobial resis tance among uropathogens that cause community acquired urinary tract infections in women: a nationwide analysis. Clin Infect Dis. 2001;33(1):89-94.

13. Woese CR, Kandler O, Wheelis ML. Towards a natural system of organisms: Proposal for the domains Archaea, Bacteria, and Eucarya. Proc Natl Acad Sci USA. 1990;87(12):4576-9.

14. Beyene G, Tsegaye W. Bacterial uropathogens in urinary tract infection and antibiotic susceptibility pattern in jimma university specialized hospital, southwest ethiopia. Ethiop J Health Sci. 2011;21(2):141-6.

15. EI Naggar W, Hassan R, Barwa R, Shokralla S, Elgaml A. Molecular diagnosis of gram negative bacteria in urinary tract infections. Egyptian J Med Microbiol. 2001;19(1):93-106.

16. Behzadi P, Behzadi E. The microbial agents of urinary tract infections at central laboratory of Dr. Shariati Hospital, Tehran, Iran. Turkiye Klinikleri J Med Sci. 2008;28(4):445.

17. Razak SK, Gurushantappa V. Bacteriology of Urinary Tract Infection and Antibiotic Susceptibility Pattern in a Tertiary Care Hospital in South India. Inter J Med Sci Public Health. 2012;1(2):109-12.

18. Bronsema DA, Adams JR, Pallares R, Wenzel RP. Secular trends in rates and etiology of nosocomial urinary tract infections at a university hospital.J Urol.1993;150:414-416.

19. Patel JB.16S rRNA gene sequencing for bacterial pathogen identification in the clinical laboratory. Mol Diagn. 2001;6(4):313-21.

20. Weber G, Riesenberg K, Schlaeffer F, Peled N, Borer A, Yagupsky $\mathrm{P}$. Changing trends in frequency and antimicrobial resistance of urinary pathogens in outpatient clinics and a hospital in southern Israel, 1991-1995. Eur J Clin Microbiol Infect Dis. 1997;16(11):834-838.

21. Carroll KC, Hale DC, Von Boerum DH, Reich GC, Hamilton LT, Matsen JM. Laboratory evaluation of urinary tract infections in an ambulatory clinic. Am J Clin Pathol. 1994;101(1):100-103.

22. Trotha R, Hanck T, König W, König B. Rapid ribosequencing-an effective diagnostic tool for detecting microbial infection. Infect. 2001;29(1):12-6.

23. Bercovici M, Kaigala GV, Liao JC, Santiago JC. . Rapid and high sensitivity detection of urinary tract infections using isothachophoresis. 14th International Conference on Miniaturized Systems for
Chemistry and Life Sciences. Groningen, The Netherlands. 2010. pp. 797-9.

24. Daniel WW. Biostatistics: A Foundation for Analysis in the Health Sciences .New York: John Wiley \& Sons; 1998.

25. Heidari Soureshjani E, Heidari M, Doosti A. Epidemiology of urinary tract infection and antibiotic resistance pattern of $\mathrm{E}$. coli in patients referred to Imam Ali hospital in Farrokhshahr, Chaharmahal va Bakhtiari, Iran. J Shahrekord Univ Med Sci. 2013;15(2):9-15.

26. Farajnia S, Alikhani MY, Ghotaslou R, Naghili B, Nakhlband A. Causative agents and antimicrobial susceptibilities of urinary tract infections in the northwest of Iran. Int J Infect Dis. 2009; 13(2):140-4.

27. Getachew T. Bacterial pathogens implicated in causing urinary tract infection (uti) and their antimicrobial susceptibility pattern in Ethiopia. Revista ENIC Ciencias Biol. 2010;41:1-6.

28. Nerurkar A, Solanky P, Naik S. Bacterial pathogens in urinary tract infection and antibiotic susceptibility pattern. $J$ Pharm Biomed Sci. 2012;21(12):1-3.

29. Mirzaei N, Rastegari H, Kargar M. Antibiotic resistance pattern among gram nnegative mercury resistant bacteria isolated from contaminated environments. Jundishapur J Microbiol. 2013;6(8):e6883.

30. Aminzadeh Z, Yadegarynia D, Fatemi A, Azad Armaki S, Aslanbeygi B. Prevalence and Antimicrobial Susceptibility Pattern of Extended Spectrum Beta Lactamase (ESBL) and non-ESBL Producing Enteric Gram-Negative Bacteria and Activity of Nitrofurantoin in the era of ESBL. Jundishapur J Microbiol. 2013;6(7):e6699.

31. Khameneh ZR, Afshar AT. Antimicrobial susceptibility pattern of urinary tract pathogens. Saudi J Kidney Dis Transpl. 2009;20(2):251-3.

32. Pezzlo M. Detection of urinary tract Infections by rapid Methods. Clin Microbiol Rev.1988;1(3):268-80.

33. Kunin CM, Febiger L. Detection, Prevention and Management of Urinary Tract Infections. 4th ed editor. Philadelphia; 1987.

34. Shanthi J, Kayathri S. Incidence, Distribution and antibiogram of uropathogens isolated from patients with urinary tract infections. Adv Appl Sci Res. 2012;3(6):3410-4.

35. Mirzarazi M, Rezatofighi SE, Pourmahdi M, Mohajeri MR. Antibiotic Resistance of Isolated Gram Negative Bacteria From Urinary Tract Infections (UTIs) in Isfahan. Jundishapur Journal of Microbiology. 2013;6(8):e6883.

36. Kashef N, Djavid GE, Shahbazi S. Antimicrobial susceptibility patterns of community-acquired uropathogens in Tehran, Iran. J Infect Dev Ctries. 2010;4(4):202-6. 